\title{
Combination Capacity and Association Among Traits of Grain Yield in Wheat (Triticum aestivum L.): A Review
}

\author{
Alexsander Rigatti ${ }^{1}$, Alan J. de Pelegrin ${ }^{2}$, Carine Meier ${ }^{1}$, Andrei Lunkes ${ }^{1}$, Luís A. Klein ${ }^{1}$, Alisson F. da Silva ${ }^{1}$, \\ Eduardo P. Bellé , Antonio D. Bortoluzzi Silva $^{1}$, Volmir S. Marchioro ${ }^{1} \&$ Velci Q. de Souza ${ }^{3}$ \\ 1 Department of Agronomic and Environmental Sciences, Federal University of Santa Maria, Frederico \\ Westphalen Campus, Frederico Westphalen, Brazil \\ ${ }^{2}$ Plant Genomics and Breeding Center, Federal University of Pelotas, Pelotas, RS, Brazil \\ ${ }^{3}$ Federal University of Pampa, Dom Pedrito, RS, Brazil \\ Correspondence: Alexsander Rigatti, Department of Agronomic and Environmental Sciences, Federal University \\ of Santa Maria, Frederico Westphalen Campus, Frederico Westphalen, Brazil. E-mail: \\ alexsanderrigatti@hotmail.com
}

Alan J. de Pelegrin, Plant Genomics and Breeding Center, Federal University of Pelotas, Pelotas, RS, Brazil. E-mail: pelegrinagro@gmail.com

Received: January 11, 2018

Accepted: February 24, 2018

Online Published: April 15, 2018

doi:10.5539/jas.v10n5p179

URL: https://doi.org/10.5539/jas.v10n5p179

\begin{abstract}
Grain yield is a complex quantitative trait, because its expression is associated to the large number of genes with small effect. In addition, there is interaction among different yield components and environment effect, making difficult the direct selection of genotypes. The most viable alternative for wheat breeding programs, an autogamous plant, is use artificial crosses in order to obtain superior genotypes. Hybridization after use of successive self-fertilizations results in segregating populations, which reveal the genetic variability, especially when the parents are genetically different. Therefore, it is important to know genetic relationships between crosses, which will serve as reference for decision making in the choice of combinations. Therefore, general combining ability (GCA) and specific combining ability (SCA) are used, which facilitate choice of the best parents to compose crossover block. In addition to these parameters, path analysis can be used to determine importance of primary and secondary traits and to guide indirect selection of promising genotypes by means of interest traits.
\end{abstract}

Keywords: quality, path analysis, plant breeding

\section{Introduction}

In quest for greater yields, wheat breeding programs tend to identify combinations ability and associations between yield traits, in order to facilitate selection of genotypes with the desired trait. In addition to productivity, quality is a desired trait aiming at higher industrial yield (Vesohoski et al., 2011). It is known that grain yield is considered a quantitative character of high complexity, due to its influence by several genes and to be involved by combination of numerous components, making it difficult the direct selection of genotypes by low heritability that it presents (Silva et al., 2005; Gondim et al., 2008).

Thus, correlation knowledge among traits is of great importance for the genetic improvement, making it possible to quantify how much a trait can influence others and to determine traits for indirect selection of genotypes. Phenotypic correlation between traits is little used in plant breeding because it is result between environmental with genetic factors interaction. However, genetic correlation presents satisfactory results considering only traits with high heritability allowing its use in breeding programs (Oliveira et al., 2007). Path analysis is a technique that is widely used in breeding programs, helping to select most viable methods for selecting individuals by estimating the direct and indirect traits influences on a main trait (Hartwig et al., 2007).

Thus, this review will address in detail how wheat breeding programs work to search wheat genotypes of high grain yield. 


\section{History of Culture}

Archaeological evidence shows that first wheat crops were carried out in 6,700 B.C. in the region of Mesopotamia, near the Tigris and Euphrates rivers in the Middle East, where Iraq is now located (Tomasini \& Ambrosi, 1998). Wheat is considered the first species to be domesticated by man, being basis for diet Asian, European and African civilizations, and its food aptitude has allowed crop to spread throughout the world's agricultural territories (Vesohoski et al., 2011).

The first wheat species to be grown by man was (Triticum monococcum L. subsp. Monococcum). For several centuries, species was cultivated until it was replaced by improved wheats. And until this day, this genotype is of interest to agriculture due to high resistance to pests and diseases, and high nutritional quality of grain. Species is considered a valuable source of genes for wheat genetic breeding in the world, mainly due to lack of genetic resistance to pests and diseases (Zaharieva \& Monneveux, 2014).

In Brazil, wheat arrived brought by Martim Afonso de Souza, in the year 1534. In the beginning, hot climate made difficult the development of the culture in the country. It was in the middle of the eighteenth century that this began to be cultivated in Rio Grande do Sul, however, crops were decimated by rust. The cultivation of this cereal only returned in the country around 1920 and from 1940, wheat cultivation expanded to the states of Rio Grande do Sul and Paraná, which became the major producers (Abitrigo, 2017).

\section{Socioeconomic Importance of Culture}

Wheat is an important cereal mainly involved in supply of raw material base to produce food products for humans and animals (Mittelmann et al., 2000). In addition, the cultivation of this cereal is of fundamental importance for small and large farms, because it integrates schemes of rotation or succession of crops, next to the soybean and corn in the system of direct seeding (Valério et al., 2008).

The world-wide area cultivated with wheat in the 2015/2016 cropping season was approximately 22.2 million hectares, with an approximate production of 736 million tons of grains, with a world average yield of 2.9 tons per hectare. The largest producers are the European Union, China and India, which together account for more than $50 \%$ of world production (USDA, 2017).

Brazil is not among the largest producers of wheat, in addition, because production does not supply demand, Brazil is among the world's largest importers of this cereal. In the 2015/2016 cropping season, the country sowed about 2.1 million hectares, reaching a production of 6.7 million tons and average yield of 3.2 tons per hectare (CONAB, 2017). This cereal is the third most cultivated agricultural species in Brazil, highlighting the South region as the largest producer. Rio Grande do Sul is the second largest producer, behind only Paraná. In the 2015/2016 cropping season, the state cultivated an area of 776.9 thousand hectares, with a total production of 2.5 million tons, with an average yield of 3.2 tons per hectare (CONAB, 2017).

\section{Classification and Botanical Characterization}

Wheat (Triticum aestivum L.) belongs to family Poaceae, tribe Triticeae, sub-tribe Triticinea and genus Triticum (Scheeren, 2011). Characterized as being an allohexaploid species (AABBDD), common wheat $(2 n=42)$ presents as a set of three complete diploid genomes. In this way, each genome comes from a species, where Triticum urartu corresponds to the AA genome, the Aegilops speltoides corresponds to the BB genome and the Aegilops tauschii corresponds to the DD genome (Brenchley et al., 2012).

The wheat plant consists of a main stem and its tillers, with each stem having the internodes, peduncle and spike. The root system is fasciculate type and leaves are composed of the sheath, blade, ligule and a pair of auricles at base of leaf blade, arranged alternately, forming an angle of $180^{\circ}$ between one leaf and another. The stem is usually hollow, cylindrical and with 4 to 7 internodes, and plant height varies in relation to the different genotypes and growth environments. The inflorescence is a compound spike, dystic, formed by alternating and opposing spikelets in rachis. The spike can vary widely in shape, density, length and width. Each spikelet consists of flowers, from 3 to 9, arranged alternately and attached to rachis. At spikelet base are two bracts called glumes. Each flower is constituted by a lemma and palea, in which, between these two structures are stigma and three anthers (Scheeren, 2011).

The grain is a fruit of caryopsis type, dry and indehiscent and can vary in shape, length and width. It is basically divided into barn, endosperm and germ. The chemical composition of wheat grain generally consists of $13 \%$ water, $13 \%$ protein, $2 \%$ oil, $2 \%$ fiber, $2 \%$ minerals and $67 \%$ starch (Scheeren et al., 2011). 


\section{Wheat Breeding}

Wheat breeding in Brazil began in 1914 with the chemist Jorge Polysú. High wheat prices on the world market, between the first and second world war, forced Federal Government to take measures to increase national production. Polysú selected several lines, in Tirol-Paraná, coming seeds from Guaporé-Rio Grande do Sul. These were known as Polysú Lines and were extremely important for wheat breeding in southern Brazil. Soon after, the cultivar PG1 was launched from Polysú Lines.

In 1938, with the creation of the Passo Fundo Experimental Station, the work of the Ministério da Agricultura in Rio Grande do Sul was resumed. In 1943, the o Instituto Agronômico do Sul-IAS was established, based in Pelotas, RS, incorporating the Experimental Stations of Pelotas and Passo Fundo, in Rio Grande do Sul; of Caçador River in Santa Catarina; and those of Ponta Grossa and Curitiba, in Paraná. Subsequently, wheat breeding in Brazil continued to be carried out by government agencies, parastatal institutions and private companies. In 1973, the Empresa Brasileira de Pesquisa Agropecuária (Embrapa), was founded. In 1974, the Centro Nacional de Pesquisa de Trigo-CNPT was set up at the Passo Fundo Experimental Station (Scheeren et al., 2011).

Basically, wheat breeding programs around the world work with aim to selecting for grain yield. For this, breeders adopt selection strategies through highly correlated traits with grain yield in segregation generations. Subsequently, when genetic material reaches a good level of homozygous and significant amounts of seeds, field trials are performed with replicates in different environments. However, in the more developed countries new techniques such as molecular genetics and cytogenetics are being studied to facilitate breeders work (Rauf et al., 2015; Drikvand et al., 2013).

Currently, most wheat breeding programs in Brazil combine efforts to obtain genotypes with tolerance to soil acidity, resistance to major wheat diseases, improvement of the agronomic type, productive potential and technological quality. These breeding programs seek the creation of cultivars with good agronomic and industrial performance (Oliveira Neto \& Santos, 2017).

\section{Grain Yield of Wheat}

Grain yield potential of crops is a very complex quantitative trait, depending on the plant's ability to produce, translocate and store carbohydrates in the grains (Sleeper \& Poelman, 2006). In this way, the genetic bases that involve grains yield of wheat, reveal greater difficulty because its expression is associated to a large number of genes with small effect, consequently, greater difficulties in the direct selection, due to the interaction among different components and environment effect.

The grain yield in wheat is determined by several components, such as number of spikes per plant, number of spikelets per spike, number of grains per spike and spikelet and average grain weight, which are strongly influenced by genetic factors and environment (Cruz et al., 2003). These components are distinctly associated with changes in the environment, either by stimuli or stress, a fact that may or may not result in changes in wheat yield (Fioreze, 2011).

In the world, wheat genetic breeding programs have shown great advances in grain yield over the years. China achieved an average increase in productivity of $1 \%$ per year in the period from 1945 to 2010, which represents a gain of $66 \mathrm{~kg} \mathrm{ha}^{-1} \mathrm{year}^{-1}$, and the grain and ear weight were main components responsible for increase in grain yield (Wu et al., 2013). The evolution in control of pests and diseases minimized consequent losses in the grain yield of wheat. Effective disease control in Sweden led to gains in productivity from 6.000 to $12.000 \mathrm{~kg} \mathrm{ha}^{-1}$ in period from 1983 to 2005, mainly associated with the increase in number of grains and weight of thousand grains (Wiik, 2009). In addition, grain yield is maximized with nitrogen application, with rates and time correct (Daba, 2017).

\section{Segregation in Crossings}

Autogamous species are characterized by high self-fertilization rate (Carvalho et al., 2008). Due to this fact, use of artificial crosses in breeding programs in this type of species becomes an important resource in order to obtain superior genotypes that attend needs of industries and consumers. This process of "hybridization" results in highly heterozygous genotypes, which, after successive self-fertilization, result in segregating populations $\left(\mathrm{F}_{2}\right.$, $\mathrm{F}_{3}, \ldots$ ) until they present a high level of alleles in homozygotes (Baldissera et al., 2014).

Breeding programs that use hybridization technique as a tool to increase variability, direct their efforts in selection of segregating populations, since they reveal genetic variability, especially when parents are genetically different (Santos et al., 2001; Benitez et al., 2011), thus increasing the possibility of selecting transgressive genotypes for interest trait (Vieira et al., 2005). 
Transgressive segregation for quantitative and qualitative traits is evidenced when progeny reveal larger magnitudes than both parents for interest traits, provided by recombination and gene rearrangement, observed from generation $\mathrm{F}_{2}$ (Carvalho et al., 2008).

The quantitative traits represent most of agronomic interest traits, and are characterized by continuous distribution. Segregation of genes involved in the inheritance of this type of trait may not be followed individually, as it is controlled by many genes (Falconer, 1981). These traits are extremely important for genetic improvement, since they make it possible to obtain estimate of variance components, and allow analysis of structure and genetic potential of segregating population (Ramalho \& Vencovsky, 1978).

\section{Diallel Analysis}

Strategies adopted in breeding programs depend on the genetic analysis of interest traits, since they lead to a better understanding of genetic relationships of the strains involved in crosses. The diallel crossings are useful for prediction the best combinations among parents and segregating populations (Valerio et al., 2009; Baldissera et al., 2012).

The researchers Sprague and Tatum (1942), Hayman (1954), and Griffing (1956) proposed diallel crossing concept, as recombination of available genetic variability within the program, occurring combination among all the parents, where from $n$ parents it is possible to obtain $\mathrm{n}^{2}$ combinations.

Diallel crosses are classified by Cruz and Regazzi (1994) in balanced or unbalanced, complete, partial, circulating and unbalanced. Among these, the most applied are those proposed by Griffing (1956), in which the effects and sums of squares of general and specific combining ability effects are estimated. Methodology proposed by Gardner and Eberhart (1966), in which evaluated effects of variety and varietal heterosis, and the one proposed by Hayman (1954), which generates information about the basic mechanism of inheritance of trait under study, the genetic values of the parents used and the limit of selection.

Griffing method (1956) is the most used, since genotypes can range from clones to pure lines, as well as being easy to analyze and interpret (Viana, 2000). Griffing (1956) systematized a diallel analysis methodology in which the "p" possible genotypes can be distributed in a $\mathrm{p} x \mathrm{p}$ table and divided into three groups: (a) p parents, (b) $p(p-1) / 2$ F1's hybrids and (c) $p(p-1) / 2$ F1's reciprocal hybrids. According to the inclusion or not of parents and/or F1's reciprocal hybrids, this methodology can be classified into four experimental designs: Method 1, where $\mathrm{p}^{2}$ combinations are included; Method 2, where $\mathrm{p}(\mathrm{p}+1) / 2$ combinations are included, excluding the F1 reciprocal hybrids; Method 3, where $\mathrm{p}(\mathrm{p}-1)$ combinations are included, excluding parents; and Method 4, where $\mathrm{p}(\mathrm{p}-1) / 2$ combinations are included, excluding parents and F1's reciprocal hybrids.

The main restriction of complete diallel crosses is exposed when there is a large number of parents involved, resulting in a large number of hybrid combinations to be evaluated, reflecting a high cost, which in many cases may be a limiting factor to the program (Veiga et al., 2000; Carvalho et al., 2004). However, if the researcher's objective is to cross a set of genetic constitutions with another set of lines, the partial diallel crossing is employed.

Dialelic analysis is used to estimate general combining ability (GCA) and specific combining ability (SCA) (Cruz \& Regazzi, 1994), and from these, to estimate the genetic parameters useful in selection of parents for hybridization, such as identification of genetic actions of control of traits, identifying also the best combinations of the lineages to be used as male parent and female parent (Verncovsky, 1987; Bernini \& Paterniani, 2012).

\section{Combination Capacity}

In genetic improvement is important to know genetic relationships between crosses, which will serve as a reference for decision making in choice of combinations. In this context, diallel analysis is used to estimate effects of overall capacity and specific combining ability (Cruz \& Regazzi, 1994). This methodology was firstly created and widely used in maize breeding, later it began to be used in autogamous species, being efficient to detect genetic differences between lines and their allocation in heterotic groups (Han et al., 1991; Gonzalez et al., 1997; Terron et al., 1997).

For Sprague and Tatum (1942) and Vencovsky (1987) general combining ability is associated with additive effect genes, being defined as average behavior of a lineage in hybrid combinations. This parameter is essential in breeding programs, since from it is possible to indicate the best crosses and select parents to integrate crossing blocks. The specific combining ability is estimated as deviation of crossover behavior from what would be expected, based on general combining ability of the parents. ECA is related to the non-additive gene effects, behavior that leads certain combinations to be higher or lower than average of the involved lines. 
According to Krystkowiak et al. (2009), the choice of suitable parents is the main step to obtain new cultivars from hybridization. For this, parents identification with high specific combining ability for desired agronomic and industrial parameters is fundamental for breeding program to reach progenies of F1 with high level of heterosis.

In addition to these two parameters, other information is available when the diallel has reciprocal crosses of hybrids (REC), that is, it is possible to indicate which genotype should be used as male parent or as female parent in a hybrid combination, according to the as well as its performance as a donor or as a pollen recipient (Baldissera et al., 2012; Rocha et al., 2014). Griffing's combining ability analysis does not require genetic assumptions (Christie \& Shattuck, 1992). Since it was proposed, it has been widely used by plant breeders and has provided reliable information on the potential for parenting combination (Viana, 2000; Pimentel et al., 2013). It is the most used technique, mainly in function of its generality, since parents can be pure lines, considering also facilities of analysis and interpretation (Pagliosa, 2012).

\section{Correlation Among Traits}

Study of correlations among traits is essential for genetic breeding, since the improvement of a particular population or genotype is directed to traits set in a joint way. This makes the estimation of correlations among traits used in order to establish adequate selection strategies (Vencovsky, 1987). The importance of the correlations for genetic breeding is justified by three main aspects: by connection with genetic causes, through pleiotropic action or genetic linkage; by connection with changes made by selection and by connection with natural selection (Falconer, 1981).

The existence of correlation among traits is crucial for breeder, because it indicates changes applied to a specific trait may cause changes in another trait. These associations quantify the possibility of indirect gains by selection, where low-heritability traits have the most efficient selection when performed on traits that are correlated with it, and which present greater heritability and ease of measurement (Cruz \& Regazzi, 1997).

Correlation is the measure of linear association between two traits, the degree to which they vary together (Steel $\&$ Torrie, 1980). Correlation is estimated by means of correlation coefficient, which quantifies degree of genetic and non-genetic association between two traits (Hallauer et al., 2010). The coefficient of correlation, is a dimensionless parameter, which varies from -1 to +1 , where the coefficient equal to zero does not imply a lack of relation between two traits, only reflects the absence of a linear association between them (Cruz \& Regazzi,1997).

In the interpretation of correlations between traits, magnitude and sign must be considered, and the magnitude indicates existence of a linear relationship among the traits studied, and the sign indicates if both traits are influenced together positively or in the as one trait increases, the other is negatively influenced, reducing its expression (Cruz, 2012).

The correlation between traits can be considered as an indicative of indirect selection, which consists of the selection applied to another trait, other than the main trait to be improved, which is called a secondary trait. Falconer (1981) pointed out several conditions to obtain efficiency in indirect selection by correlation, among them: that the heritability of selected trait must be greater than that of trait to be improved and genetic correlation between two traits should be high. However, this same author said that indirect selection will only be more efficient than direct selection in cases that concern technical difficulties, when applying direct selection in interest trait to be improved. These technical difficulties are related to precision in measurement of the trait, to the occurrence of desired trait in only one sex, while secondary trait can be measured in both sexes.

The phenotype of an individual is determined by its genetic constitution (genotype) and by environment effect, being the Phenotype $(\mathrm{F})=$ Genotype $(\mathrm{G})+$ Environment $(\mathrm{E})$. Faced with this, phenotype is a result of joint action of genotypic and environment effects in which plant is exposed. The association between two traits can be directly measured in a group of individuals is denominated a phenotypic correlation. This is based on the measurement of phenotype, being influenced by two causes, first genetic and second environmental (Falconer, 1981).

Phenotypic associations between two characters are important, because they allow to evaluate indirect selection viability, however, its use hasty form can lead to erroneous conclusions, reducing its practical applicability (Carvalho et al., 2004). In this context, if the main trait has low heritability, phenotypic correlation is determined mainly by environment correlation. On the other hand, if trait presents high heritability phenotypic correlation is due to genetic correlation (Falconer, 1981). 
Breeder needs to be aware of genotype changes in different environments and interaction level between genotype and environment, in order to efficiently select a genotype with desired agronomic parameters. In addition, it is necessary to quantify genotype and environment individual action and their interaction. With these three factors it is possible to estimate heritability of interest traits, knowing that higher heritability may selection easier of trait in question (Williams et al., 2008).

\section{Path Analysis}

Path analysis was first described by Wright (1921) and used in 1923 in order to promote a better understanding of the associations among traits, due to the unfolding of the simple correlations. The methodology allows quantifying both magnitude and direction of associations among traits in a more complex way, revealing importance of the direct and indirect effects on dependent trait (Cruz et al., 2014).

This analysis is characterized by conferring associations that reveal cause and effect interrelationships on traits studied. In genetic breeding, the technique is used to determine importance of primary and secondary traits and to guide the indirect selection of promising genotypes, through of interest traits (Cruz et al., 2014).

Path analysis is determined through a standardized coefficient that allows to correlate traits measured in different physical units, not presenting notations in their results (Cruz et al., 2014). In genetic breeding, it seeks to identify traits that show high correlation with main trait, however, opposite direction between total correlation and its direct effects indicate absence of cause and effect association (Cruz et al., 2006).

The knowledge of cause and effect relationships among allows breeder to understand the importance of each trait under expression of others, since indirect selection based only on linear association among traits may reveal modifications in desirable traits (Santos et al., 2000).

However, path analysis is known to be based on multiple regressions involving many highly correlated characters. In this way, it is difficult to quantify individually relation of explanatory traits with dependent character, since traits contribute collectively, resulting multicollinearity. When this occurs, correlation coefficients generated by path analysis become unreliable, and adjustments must be made in correlation matrix (Olivoto et al., 2017; Stage et al., 2004).

\section{Conclusion}

Wheat breeding improvement seeks to select superior genotypes of to meet the agronomic and industrial parameters. For this, interactions knowledge among components traits is important paramount for breeding programs success. Thus, methods are used to identify existence of correlation among traits to choose the best selection strategy. Among methods, it is worth noting path analysis, which allows to understand traits influence on grain yield of grains and choice for traits that indirect act with greater magnitude on interest traits.

\section{References}

Abitrigo. (2017). Associação Brasileira da indústria do trigo. O Trigo na história. Retrieved from http://www. abitrigo.com.br/trigo-na-historia.php

Baldissera, J. N. C., Valentini, G., Coan, M. M. D., Guidolin, A. F., \& Coimbra, J. L. M. (2014). Fatores genéticos relacionados com a herança em populações de plantas autógamas. Revista de Ciências Agroveterinárias, 13(2), 181-189.

Baldissera, J. N. C., Valentini, G., Com, M. M. D., Almeida, C. B., Guidolin, A. F., \& Coimbra, J. F. M. (2012). Capacidade combinatória e efeito recíproco em características agronômicas do feijão. Semina: Ciências Agrárias, 33(2), 471-480. https://doi.org/10.5433/1679-0359.2012v33n2p471

Benitez, L. C., Rodrigues, I. C. S., Arge, L. W. P., Ribeiro, M. V., \& Braga, E. J. B. (2011). Análise multivariada da divergência genética de genótipos de arroz sob estresse salino durante a fase vegetativa. Revista Ciência Agronômica, 42(2), 409-416.

Bernini, C. S., \& Paterniani, M. E. A. G. Z. (2012). Estimativas de parâmetros de heterose em híbridos de populações $\mathrm{F}_{2}$ de milho. Pesquisa Agropecuária Tropical, 42, 56-62. https://doi.org/10.1590/S1983-4063 2012000100008

Brenchley, R., Spannagl, M., PfeifeR, M., Barker, G. L. A., D’Amore, R., Allen, A. M., ... Hall, N. (2012). Analysis of the bread wheat genome using whole-genome shotgun sequencing. Nature, 491, 705-710. https://doi.org/10.1038/nature11650

Carvalho, F. I. F., Lorencetti, C., \& Benin, G. (2004). Estimativas e implicações da correlação no melhoramento genético (p. 142). Pelotas: UFPel. 
Carvalho, F. I. F., Lorencetti, C., Marchioro, V., \& Silva, S. A. (2008). Condução de populações no melhoramento genético de plantas (p. 288). Pelotas: UFPel.

Christie, B. R., \& Shattuck, V. (1992). I. 2-The Diallel Cross: Design, Analysis, and Use for Plant Breeders. Plant Breeding Reviews, 9.

CONAB (Companhia Brasileira de Abastecimento). (2017). Acompanhamento da safra Brasileira de grãos, safra 2016/2017. Sexto Levantamento (No. 4). Retrieved March 12, 2017, from http://www.conab.gov.br/Olala CMS/uploads/arquivos/17_03_14_15_28_33_boletim_graos_marco_2017bx.pdf

Cruz, C. D. (2012). Princípios de genética quantitativa (1st ed., p. 394). Viçosa: Editora UFV.

Cruz, C. D., \& Carneiro, P. C. S. (2006). Modelos Biométricos Aplicados ao Melhoramento Genético (3rd ed., p. 586) Viçosa: UFV.

Cruz, C. D., \& Regazzi, A. J. (1994). Modelos biométricos aplicados ao melhoramento genético (p. 390). Viçosa: UFV.

Cruz, C. D., \& Regazzi, A. J. (1997). Modelos biométricos aplicados ao melhoramento genético (2nd ed., p. 390). Viçosa: Editora UFV.

Cruz, C. D., Carneiro, P. C. S., \& Regazzi, A. J. (2014). Modelos biométricos aplicados ao melhoramento genético (3rd ed., p. 668). Viçosa, MG: UFV.

Cruz, P. J., Carvalho, F. I. F. de, Silva, S. A., Kurek, A. J., Barbieri, R. L., \& Cargnin, A. (2003). Influência do acamamento sobre o rendimento de grãos e outros caracteres em trigo. Revista Brasileira de Agrociências, 9(1), 05-08.

Daba, N. A. (2017). Influence of nitrogen fertilizer application on grain yield, nitrogen uptake efficiency, and nitrogen use efficiency of bread wheat (Triticum aestivum L.) Cultivars in eastern Ethiopia. Journal of Agricultural Science, 9(7), 202-217. https://doi.org/10.5539/jas.v9n7p202

Drikvand, R., Bihamta, M. R., Najafian, G., \& Ebrahimi, A. (2013). Investigation of genetic diversity among bread wheat cultivars (Triticum aestivum L.) using SSR markers. Journal of Agricultural Science, 5(1), 122-129. https://doi.org/10.5539/jas.v5n1p122

Falconer, D. S. (1981). Introdução à genética quantitativa (p. 279). Viçosa: Imprensa Universitária da UFV.

Fioreze, S. L. (2011). Comportamento produtivo do trigo em função da densidade de semeadura e da aplicação de reguladores vegetais [74 f., Dissertação (Mestrado em Agronomia), Universidade Estadual Paulista, Faculdade de Ciências Agronômicas, Botucatu].

Gardner, C. O., \& Eberhart, S. A. (1966). Analysis and interpretation of the variety cross diallel and related populations. Biometric, 22, 439-452. https://doi.org/10.2307/2528181

Gondim, T. C. O., Rocha, V. S., Sediyama, C. S., \& Miranda, G. V. (2008). Análise de trilha para componentes do rendimento e caracteres agronômicos de trigo sob desfolha. Pesquisa Agropecuária Brasileira, 43(4), 487-493. https://doi.org/10.1590/S0100-204X2008000400007

Gonzalez, S., Cordova, H., Rodriguez, S., De Leon, H., \& Serrato, V. M. (1997). Determinacion de um patrón heterótico a partir de la evaluacion de undialelo de diezlineas de maiz subtropical. Agronomia Mesoamericana, 8, 1-7.

Griffing, B. (1956). Concept of general and specific ability in relation to diallel crossing systems. Australian Journal of Biological Sciences, 9(4), 462-93.

Hallauer, A. R., Carena, M., \& Miranda Filho, J. B. (2010). Quantitative genetics in maize breeding (3rd ed.). Ames: Iowa State University.

Han, G. C., Vasal, S. K., Beck, D. L., \& Elias, E. (1991). Combining ability of inbred lines derived from CIMMYT maize (Zea mays L.) germplasm. Maydica, 36, 57-64.

Hartwig, I., Carvalho, F. I. F., Oliveira, A. C., Vieira, E. A., Silva, J. A. G., Bertan, I., ... Busato, C. C. (2007). Estimativa de coeficientes de correlação e trilha em gerações segregantes de trigo hexaplóide. Bragantia, 66(2). https://doi.org/10.1590/S0006-87052007000200004

Hayman, B. I. (1954). The theory and analysis of diallel crosses. Genetics, 39, 789-809. 
Krystkowiak, K., Adamski, T., Surma, M., \& Kaczmarek, Z. (2009). Relação entre a diversidade fenotípica e genética dos genótipos parentais e a capacidade de combinação específica e os efeitos de heterose no trigo (Triticum aestivum L.). Euphytica, 65(3), 419-434. https://doi.org/10.1007/s10681-008-9761-y

Mittelmann, A., Neto, J. F. B., Carvalho, F. I. F., Lemos, M. C. I., \& Conceição, L. D. H. (2000). Herança de caracteres do trigo relacionados a qualidade de panificação. Pesquisa Agropecuária Brasileira, 35(5), 975-983. https://doi.org/10.1590/S0100-204X2000000500015

Oliveira Neto, A. A. de, \& Santos, C. M. R. (2017). A cultura do trigo (p. 218). Brasília: CONAB.

Oliveira, A. C., Vieira, E., Carvalho, F., Martins, L., Benin, G., Silva, J. A., ... Ribeiro, G. (2007). Análise de trilha entre os componentes primários e secundários do rendimento de grãos em trigo. Current Agricultural Science and Technology, 13(2). https://doi.org/10.18539/cast.v13i2.1357

Olivoto, T., de Souza, V. Q., Nardino, M., Carvalho, I. R., Ferrari, M., de Pelegrin, A. J., ... Schmidt, D. (2017). Multicollinearity in Path Analysis: A Simple Method to Reduce Its Effects. Agronomy Journal, 109(1), 131-142. https://doi.org/10.2134/agronj2016.04.0196

Pagliosa, E. S. (2012). Metodologias de análise dialélica como critério para a seleção de genitores de trigo [66 f., Dissertação (Mestrado em Agronomia), Universidade Tecnológica Federal do Paraná, Pato Branco].

Pimentel, A. J. B., Ribeiro, G., Souza, M. A. de, Moura, L. M., Assis, J. C. de, \& Machado, J. C. (2013). Comparação de métodos de seleção de genitores e populações segregantes aplicados ao melhoramento de trigo. Bragantia, 72, 113-121. https://doi.org/10.1590/S0006-87052013005000026

Ramalho, M. A. P., \& Vencovsky, R. (1978). Estimação dos componentes da variância genética em plantas autógamas. Ciência e Prática, 2, 117-140.

Rauf, S., Zaharieva, M., Warburton, M. L., Zhang, P. Z., Al-Sadi, A. M., Khalil, F., ... Tariq, S. A. (2015). Breaking wheat yield barriers requires integrated efforts in developing countries. Journal of Integrative Agriculture, 14(8), 1447-1474. https://doi.org/10.1016/S2095-3119(15)61035-8.

Rocha, F., Stinghen, J. C., Murielli, S. G., Coimbra, J. L. M., \& Guidolin, A. F. (2014). Análise dialélica como ferramenta na seleção de genitores de feijão. Revista Ciência Agronômica, 45(1), 74-81.

Santos, P. G., Soares, A. A., \& Ramalho, M. A. P. (2001). Predição do potencial genético de populações segregantes de arroz em terras altas. Pesquisa Agropecuária Brasileira, 36(4). https://doi.org/10.1590/ S0100-204X2001000400009

Santos, R. C., Carvalho, L. P., \& Santos, V. F. (2000). Análise de coeficiente de trilha para componentes de produção de amendoim. Ciência e Agrotecnologia, 24(1), 13-16.

Scheeren, P. L., Caierão, E., Só e Silva, M., \& Bonow, S. (2011). Melhoramento de trigo no Brasil. In J. L. F. Pires, L. Vargas, \& G. R. da Cunha (Eds.), Trigo no Brasil: Bases para a produção competitiva e sustentável (pp. 427-451). Passo Fundo: Embrapa Trigo.

Silva, S. A., Cruz, P. J., Carvalho, F. I. F. D., Nedel, J. L., Silva, J. A. G. D., Caetano, V. D. R., ... Sousa, C. D. S. (2005). Análise de trilha para os componentes de rendimento de grãos em trigo. Bragantia, 64(2), 191-196 https://doi.org/10.1590/S0006-87052005000200004

Sleper, D. A., \& Poehlman, J. M. (2006). Breeding field crops (p. 424). Ames: Blackwell Pub Iowa.

Sprague, G. F., \& Tatum, L. A. (1942). General vs. specific combining ability in single crosses of corn. Journal of the American Society of Agronomy, 34(10), 923-932.

Stage, F. K., Carter, H. C., \& Nora, A. (2004). Path analysis: An introduction and analysis of a decade of research. The Journal of Educational Research, 98(1), 5-13. https://doi.org/10.3200/JOER.98.1.5-13

Steel, R. G. D., \& Torrie, J. H. (1980). Principles and procedures of statistics: a biometrical approach (p. 633). New York: McGraw-Hill Book Company.

Terron, A., Preciado, E., Córdova, H., Mickelson, H., \& López, R. (1997). Determinacion del patron heterotico de 30 lineas de maiz derivadas de la poblacion 43SR del CIMMYT. Agronomia Mesoamericana, 8, 26-34.

Tomasini, R. G. A., \& Ambrosi, I. (1998). Aspectos econômicos da cultura de trigo. Caderno de Ciência \& Tecnologia, 15(2), 59-84.

USDA (United States Department of Agriculture). (2017). Statistics of grain and feed. Retrieved March 10, 2017, from https://www.nass.usda.gov/Statistics_by_Subject/index.php?sector=CROPS 
Valério, I. P., Carvalho, F. I. F., Oliveira, A. C., Benin, G., Maia, L. C., Silva, J. A. G., ... Silveira, G. (2009). Factors related to the production and development of tillers in wheat. Semina: Ciências Agrárias, 30(4), 1207-1218. https://doi.org/10.5433/1679-0359.2009v30n4Sup1p1207

Valério, I. P., Carvalho, F. I. F., Oliveira, A. C., Machado, A. A., Benin, G., Scheeren, P. L., ... Hartwig, I. (2008). Desenvolvimento de afilhos e componentes do rendimento em genótipos de trigo sob diferentes densidades de semeadura. Pesquisa Agropecuária Brasileira, 43(3), 319-326. https://doi.org/10.1590/S0100-204X20 08000300005

Veiga, R. D., Ferreira, D. F., \& Ramalho, M. A. P. (2000). Eficiência dos dialelos circulantes na escolha de genitores. Pesquisa Agropecuária Brasileira, 35, 1395-1406. https://doi.org/10.1590/S0100-204X20000 00700014

Vencovsky, R. (1987). Herança quantitativa. In E. Paterniani, \& G. P. Viegas (Eds.), Melhoramento e produção do milho (2nd ed., pp. 137-214). Campinas: Fundação Cargill.

Vesohoski, F., Marchioro, V. S., Franco, F. A., \& Cantelle, A. (2011). Componentes de rendimento de grãos em trigo e seus efeitos diretos e indiretos na produtividade. Revista Ceres, 58(1), 337-341.

Viana, J. M. S. (2000). The parametric restrictions of the Griffing diallel analysis model: Combining ability analysis. Genetics and Molecular Biology, 23(4), 877-881. https://doi.org/10.1590/S1415-47572000000 400029

Vieira, E. A., Zimmer, P. D., Oliveira, A. C., Carvalho, F. I. F., Malone, G., \& Benin, G. (2005). Emprego de modelos gráficos na seleção de genitores de milho para hibridização e mapeamento genético. Ciência Rural, 35(5), 986-994. https://doi.org/10.1590/S0103-84782005000500002

Wiik, L. (2009). Yield and disease control in winter wheat in southern Sweden during 1977-2005. Crop Protection, 28(1), 82-89. https://doi.org/10.1016/j.cropro.2008.09.002

Williams, R. M., O’Brien, L., Eagles, H. A., Solah, V. A., \& Jayasena, V. (2008). The influences of genotype, environment, and genotype $\times$ environment interaction on wheat quality. Australian Journal of Agricultural Research, 59(2), 95-111. https://doi.org/10.1071/AR07185

Wright, S. (1921). Correlation and causation. Journal of Agricultural Research, 20, 557-585.

Wu, W., Li, C., Ma, B., Shah, F., Liu, Y., \& Liao, Y. (2014). Genetic progress in wheat yield and associated traits in China since 1945 and future prospects. Euphytica, 196(2), 155-168. https://doi.org/10.1007/s10681-0131033-9

Zaharieva, M., \& Monneveux, P. (2014). Cultivated einkorn wheat (Triticum monococcum L. subsp. monococcum): The long life of a founder crop of agriculture. Genetic Resources and Crop Evolution, 61(3), 677-706. https://doi.org/10.1007/s10722-014-0084-7

\section{Copyrights}

Copyright for this article is retained by the author(s), with first publication rights granted to the journal.

This is an open-access article distributed under the terms and conditions of the Creative Commons Attribution license (http://creativecommons.org/licenses/by/4.0/). 